\title{
NYMPHICIDAL AND OVIPOSITIONAL EFFICACY OF SEAWEED Sargassum tenerrimum (J. Agardh) AGAINST Dysdercus cingulatus (Fab.) (PYRRHOCORIDAE)
}

\author{
Kitherian Sahayaraj $^{1 *}$, and Y. Mary Jeeva ${ }^{1}$
}

We investigated the role of a brown seaweed alga, Sargassum tenerrimum (J. Agardh), against Dysdercus cingulatus (Fab.), which is an economically important cotton pest in many parts of Asia. Sargassum tenerrimum has been used as a source of fertilizers and drugs, but there is no information available in the literature about its use in ecofriendly pest management. The impact of benzene $(\mathrm{BN})$, chloroform $(\mathrm{CH})$, and a mixture of benzene and chloroform $(\mathrm{BNCH})$ extracts, as well as two chromatographic fractions of BNCH (FR1 and FR2) were investigated for their insecticidal and ovipositional properties against $D$. cingulatus. The $\mathrm{BE}$ extract showed the best insecticidal activity $\left(\mathrm{LC}_{50}=0.009 \%\right)$, higher than $\mathrm{BNCH}\left(\mathrm{LC} \mathrm{C}_{50}=\right.$ $0.021 \%$ ) and $\mathrm{CH}$ extracts $\left(\mathrm{LC}_{50}=0.2481 \%\right)$, and all the extracts reduced the total nymphal developmental period of the pest in a dose-dependent way. Adult longevity of both males and females was reduced by the $\mathrm{CH}$ and $\mathrm{BE}$ extracts. The $\mathrm{CH}$ extract reduced $D$. cingulatus oviposition, preoviposition, and post-oviposition periods, as well as fecundity. Females emerging from the BE category could not lay eggs. All the extracts significantly reduced both total body protein and genomic DNA content. The BECH fractions, FR1 and FR2, also exhibited nymphicidal activity against the pest. However, these fractions did not significantly alter the nymphal developmental period. Results indicate that these seaweed extracts can be used as biopesticides for pest management.

Key words: Dysdercus cingulatus, cotton pest, nymphicidal, ovipositional, Sargassum tenerrimum, seaweed, pest management.

$\mathrm{I}^{\mathrm{n}}$ $\mathrm{n}$ India, cotton production is about 295 million bales $(\approx$ $480 \mathrm{lb}$ bales) during 2009-2010 against 113.9 million bales in the rest of the world. India also has the largest area under cotton cultivation (10.31 million ha), and yield was $486 \mathrm{~kg} \mathrm{ha}^{-1}$ during 2009-2010 (Cotcorp, 2010). Cotton is damaged by over 160 insect species from the seeding stage right through the whole plant growth period. The cotton stainer, Dysdercus cingulatus (Fab.) (Heteroptera: Pyrrhocoridae), causes serious damage by feeding on developing cotton bolls and ripe cotton seeds and by transmitting fungi that develop on the immature lint and seeds (Yasuda, 1992; Natarajan and Rajendran, 2005). The pest is very difficult to control by insecticides because of its high mobility (Iwata, 1975), its many alternative wild hosts (Kohno and Thi, 2004), and a polymorphic nature (Sahayaraj and Ilyaraja, 2008). Rajendran and Gopalan (1980) studied the impact of Catharanthus roseus (L.) G. Don. (Astraceae), Parthenium hysterophorus L. (Apocynaceae), and Nephrolepis exaltata (L.) Schott (Nephrolepidaceae) extracts on the morphological

${ }^{1}$ Crop Protection Research Centre, Department of Advanced Zoology and Biotechnology, St. Xavier's College (Autonomous), Palayamkottai 627 002, Tamil Nadu, India.

*Corresponding author (ksraj42@gmail.com).

Received: 12 June 2011.

Accepted: 22 November 2011. changes of $D$. cingulatus. The impact of different neem part extracts on $D$. cingulatus mortality has also been studied (Sharma et al., 2010). Pedalium murex (L.) (Sahayaraj et al., 2006) and Streblus asper Lour. (Hashim and Devi, 2003) root extracts prolonged D. cingulatus mating duration and reduced its fecundity, hatchability, and adult longevity. Along with terrestrial plants, seaweeds have now been used for pest management programs. Dureja (1993), Rizvi (2003), and Rizvi and Shameel (2003, 2004) highlighted the importance of algal seaweeds in insect pest management. Biju et al. (2004), Manilal et al . (2009), and Sahayaraj and Kalidas (2011) have recorded the insecticidal activity of seaweeds such as Bryopsis plumosa (Huds.), Padina pavonica (Linn.), and Hyblaea puera (Cram.) on D. cingulatus and Culex quinquefasciatus, respectively.

Sargassum spp. is distributed in almost all the coasts of the world, including Spain's north and eastern Atlantic coast. A critical survey of the literature reveals that Sargassum tenerrimum has not been studied on any agricultural pests for its pesticidal property. Furthermore, more than 2500 terrestrial plants have been screened against agricultural pests; however, scientists have developed insecticides only from the neem. Hence, it is imperative to evaluate the insecticidal activity of marine plants. Drifted S.tenerrimum is merely a waste in many parts of the world, and it can be used for pest management programs. 
The objective of our study was to explore under laboratory conditions Sargassum tenerrimum to combat D. cingulatus, the devastating and notorious cotton pest.

\section{MATERIALS AND METHODS}

Drifted $S$. tenerrimum was collected from the coastal area of the Kanyakumari District of Tamil Nadu, India. Immediately after being collected, the alga was washed in sea water, and epiphytes, associated organisms, sand, and other extraneous matter were removed. Subsequently, the plants were washed in fresh water and shade-dried for $2 \mathrm{wk}$. Then, they were partially powdered with a domestic blender and stored in airtight containers until needed. From the stock, $500 \mathrm{~g}$ of powdered material was extracted for each of benzene (BN), chloroform $(\mathrm{CH})$, and a benzene and chloroform mixture $(\mathrm{BNCH})$ at a 2:1 ratio with a Soxhlet apparatus for $24 \mathrm{~h}$ at $50{ }^{\circ} \mathrm{C}$. The extract was concentrated with a distillation apparatus at $40{ }^{\circ} \mathrm{C}$ and concentrated again with vacuum desiccators at room temperature to obtain a minimum quantity of crude extract to test insecticidal activity on $D$. cingulatus.

Dark-green colored BECH extract (2.140 g) was further fractionated by a silica gel (60-120 mesh) $100 \mathrm{~g}$ column with solvents such as $\mathrm{CH}$, glacial acetic acid (GAA), diethyl ether, and methanol. Elution with different proportions of CH:GAA (7:3) combined to yield light-green (FR1) and greenish-yellow (FR2) compounds. Later, they were spotted on the preparative thin layer chromatography (TLC) plate (Silica gel 60 F254 Aluminum plate) and observed under white light and UV $365 \mathrm{~nm}$. The eluted fractions, FR1 and FR2, were tested against third instar nymphs of the red cotton bug by dermal bioassay.

Dysdercus cingulatus nymphs and adults were collected from cotton fields in the Tirunelveli District of Tamil Nadu, India, and subsequently maintained in the laboratory at $28 \pm 2{ }^{\circ} \mathrm{C}$ and $70-75 \% \mathrm{RH}$ on watersoaked cotton seeds and fresh cotton leaves. The nymphs emerged from the egg masses laid in the laboratory were reared using cotton plants, and newly emerged third instar nymphs were employed for the experiments. Each treatment contained six replicates with 10 insects for each replicate. Sahayaraj and Kalidas's (2011) seed dip method was followed for the insecticidal activity bioassay.

Five concentrations $(0.1 \%, 0.2 \%, 0.4 \%, 0.8 \%$, and $1.6 \%$ ) were prepared with $1 \mathrm{~mL}$ of the respective solvents, which were then diluted with $10 \mathrm{~mL}$ water for use in the study. Cotton seeds $(100 \mathrm{~g})$ were taken separately in a conical flask and $250 \mathrm{~mL}$ of plant extract and $3 \mathrm{~mL}$ of Tween $80(0.1 \%)$, as an adjuvant, were added. The flask was agitated at $65 \mathrm{rpm}$ in a shaker (Remi, Mumbai) for $12 \mathrm{~h}$ at room temperature and fed to D. cingulatus. Ten third instar $D$. cingulatus nymphs were taken in a plastic container $(300 \mathrm{~mL}$ capacity) that was covered with an aerated lid. The control was water mixed with adjuvant in which cotton seeds were soaked. For both the experiment and the control, cotton seeds were replaced every day by new plant extracts of seeds soaked for $4 \mathrm{~d}$. Mortality was recorded at $24,48,72$, and $96 \mathrm{~h}$.

For fractions, 10 nymphs were released into the Petri dish. Mixed adjuvant fractions were sprayed separately with a hand sprayer. Water-soaked cotton seeds were given to the insects after treatment, and mortality was recorded at $24,48,72$, and $96 \mathrm{~h}$. The control was maintained with its respective solvents. Mortality data were corrected by Abbott (1925) and $\mathrm{LC}_{50}$ s determined according to Finney (1971). After $94 \mathrm{~h}$, live insects were maintained on water-soaked cotton seeds until they died. Total nymphal developmental period, sex ratio (female + male/female), and adult longevity were recorded. Emerged adults were maintained in plastic containers $(350 \mathrm{~mL}$ capacity) in pairs (male:female) until they died. Preoviposition period, oviposition period, postoviposition period, number of eggs laid by a female, and egg hatchability percentage were recorded. Moribund insects were used for analyses of total body protein (Bradford, 1976) and total genomic DNA content (Sambrook et al., 1989). Data obtained in experimental treatments were compared with the control by Student's t-test and expressed at a $5 \%$ significance level.

Both qualitative and quantitative (total phenols [mg $\mathrm{g}^{-1}$ ], ortho dihydric phenols [ODP], bound phenols [BP] $\left[\mu \mathrm{g} \mathrm{mg}^{-1}\right.$ ], and tannins $\left[\mathrm{mg} \mathrm{g}^{-1}\right]$ ) phytochemical analyses of the extracts was carried out following Harbone's (1998) method.

All results were expressed as means with standard errors. Individual data was subjected to one-way ANOVA and post ANOVA Tukey Multiple Range Test (TMRT), and significance expressed at a 5\% level.

\section{RESULTS}

\section{Phytochemical analyses}

Phytochemical investigation revealed the presence of steroids, reducing sugars, alkaloids, phenolic compounds, saponin, xanthoprotein, and flavonoids in the $S$. tenerrimum extracts. Steroids, phenolic compounds, and saponin were recorded from all three extracts, whereas alkaloids and xanthoprotein were not recorded from the S. tennerimum $\mathrm{CH}$ extract. Flavonoids were only in the plant's BNCH. Quantitative estimates of the S.tenerrimum extract revealed that the extracts contained $07.2687 \mathrm{mg} \mathrm{g}^{-1}$ total phenols, were mainly located at the stem (14.7116

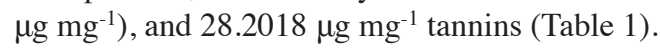

\section{Insecticidal activity}

Sargassum tenerrimum extracts caused dose-dependent mortality. Among the three extracts, BE was highly toxic, followed by the $\mathrm{BNCH}$ and $\mathrm{CH}$ extracts against D. cingulatus third instar nymphs (Table 2). Similarly, 
Table 1. Quantity of total phenols, ortho dihydric phenols (ODP), bound phenols (BP), and tannins in Sargassum tennerimum.

\begin{tabular}{lcllc}
\hline Plant parts & Total phenols & \multicolumn{1}{c}{ ODP } & \multicolumn{1}{c}{ BP } & Tannins \\
\hline & $\mathrm{mg} \mathrm{g}^{-1}$ & \multicolumn{1}{c}{$\mu \mathrm{g} \mathrm{mg}^{-1}$} & $\mathrm{mg} \mathrm{g}^{-1}$ \\
Whole plant & 07.2687 & 0.2958 & 0.2359 & 28.2018 \\
Leaf & 04.5701 & 0.01867 & 0.3322 & 28.007 \\
Stem & 14.7116 & 0.0814 & 0.2452 & 24.5795 \\
Petiole & 06.0065 & 0.05619 & 0.2747 & 20.6985 \\
\hline
\end{tabular}

Table 2. Effective concentrations (\%) of $\mathrm{LC}_{30}, \mathrm{LC}_{50}$, and $\mathrm{LC}_{90}$, regression equation, variance and Chi-square value of Sargassum tenerrimum extracts against Dysdercus cingulatus nymphs.

\begin{tabular}{lcccccc}
\hline $\begin{array}{l}\text { Exposure } \\
\text { time }(\mathrm{h})\end{array}$ & $\begin{array}{c}\text { Regression } \\
\text { equation }\end{array}$ & $\mathrm{LC}_{30}$ & $\mathrm{LC}_{50}$ & $\mathrm{LC}_{90}$ & Variance & $\begin{array}{c}\text { Calculated } \\
\text { Chi-square } \\
\text { value }\end{array}$ \\
\hline \multicolumn{7}{c}{ Benzene extract } \\
24 & $\mathrm{Y}=1.761 \mathrm{x}+1.90$ & 0.4283 & 0.574 & 0.7693 & 0.0042 & 4.81 \\
48 & $\mathrm{Y}=1.070 \mathrm{x}+4.11$ & 0.0490 & 0.068 & 0.0858 & 0.0495 & 1.04 \\
72 & $\mathrm{Y}=0.874 \mathrm{x}+4.90$ & 0.0126 & 0.013 & 0.0163 & 0.3137 & 0.18 \\
96 & $\mathrm{Y}=0.807 \mathrm{x}+5.03$ & 0.0087 & 0.009 & 0.0120 & 0.4770 & 0.13 \\
\multicolumn{7}{c}{ Chloroform extract } \\
24 & $\mathrm{Y}=3.7065 \mathrm{x}+2.38$ & 0.3526 & 0.6677 & 1.2649 & 0.0012 & 1.88 \\
48 & $\mathrm{Y}=3.9091 \mathrm{x}+2.39$ & 0.3340 & 0.5265 & 0.8300 & 0.0344 & 1.61 \\
72 & $\mathrm{Y}=4.0862 \mathrm{x}+2.38$ & 0.3138 & 0.4059 & 0.5249 & 0.0378 & 1.32 \\
96 & $\mathrm{Y}=4.9325 \mathrm{x}+2.40$ & 0.2285 & 0.2481 & 0.2695 & 0.0213 & 4.34 \\
78 & $\mathrm{Benzene}+$ chloroform extract & & \\
24 & $\mathrm{Y}=1.173 \mathrm{x}+2.84$ & 0.4351 & 0.700 & 1.125 & 0.0111 & 1.61 \\
48 & $\mathrm{Y}=1.276 \mathrm{x}+3.35$ & 0.1209 & 0.195 & 0.214 & 0.0112 & 1.93 \\
72 & $\mathrm{Y}=1.676 \mathrm{x}+3.50$ & 0.0720 & 0.078 & 0.0816 & 0.0268 & 2.97 \\
96 & $\mathrm{Y}=1.166 \mathrm{x}+4.64$ & 0.0216 & 0.021 & 0.0704 & 0.2202 & 0.76 \\
\hline
\end{tabular}

$\mathrm{BE}$ significantly $(\mathrm{P}<0.05)$ reduced the total nymphal developmental period and more than the $\mathrm{BNCH}$ and $\mathrm{CH}$ extracts (Table 3). Sex ratio was female-biased in the control $(0.64)$ and significantly $(\mathrm{P}<0.05)$ lower in the $S$. tenerrimum $\mathrm{CH}$ extract $(0.56)$ and followed by the BE extracts $(0.25)$. Adults that emerged from treatments with cotton seeds soaked in water lived longer (15 and $19 \mathrm{~d}$ for male and female, respectively), but this was reduced by S. tenerrimum $\mathrm{CH}$ and $\mathrm{BE}$ extracts (Figure 1). Adults died immediately after molting in $\mathrm{BNCH}$ and did not lay any eggs even after successful mating in the BE extract treatment. The $\mathrm{CH}$ extract did not have any effect on the length of pre- and postoviposition periods, but it significantly reduced $(\mathrm{P}<0.05)$ fecundity by $27.7 \%$ and egg hatchability by $40.8 \%$ (Table 4 )

However, fractions of $S$. tenerrimum did not have any significant $(\mathrm{P}>0.05)$ impact on the development of $D$. cingulatus (Table 5). The $S$. tenerrimum FR1 fraction significantly $(\mathrm{P}<0.05)$ caused more mortality $(60 \%)$ than FR2 (30\%) (Figure 2). Total body protein content of $D$. cingulatus was $26.12 \mathrm{mg} 100 \mathrm{mg}^{-1}$, and it was significantly $(\mathrm{P}<0.05)$ reduced by the $S$. tenerrimum BECH extract (55.82\%), and followed by the BE (31.55\%) and $\mathrm{CH}(14.77 \%)$ extracts (Figure 3). On the other hand, benzene highly reduced total body genomic DNA content (31.52\%), followed by $\mathrm{CH}(27.17 \%)$ and $\mathrm{BECH}(25.54 \%)$ (Figure 4).

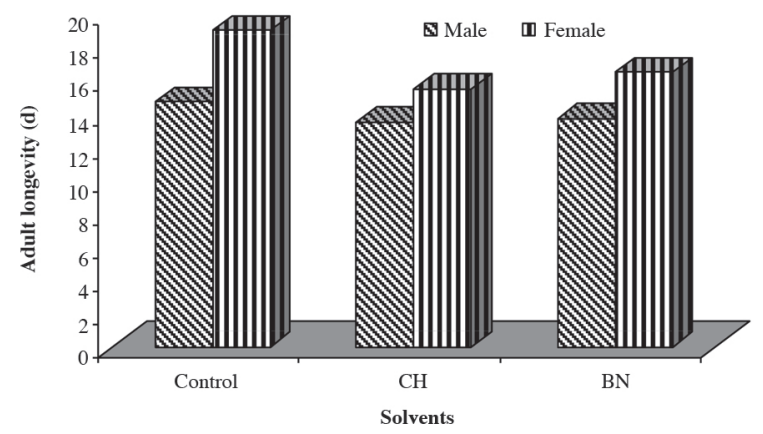

Figure 1. Impact of Sargassum tenerrimum benzene (BE), and chloroform (CH) extracts on adult Dysdercus cingulatus longevity.

Table 3. Percentage content of five crude extracts of Sargassum tenerrimum on the total nymphal developmental period (d) of Dysdercus cingulatus.

\begin{tabular}{|c|c|c|c|c|c|}
\hline \multirow[b]{2}{*}{ Extract } & \multicolumn{5}{|c|}{ Concentrations (\%) } \\
\hline & 0.1 & 0.2 & 0.4 & 0.8 & 1.6 \\
\hline Chloroform & $19.79 \pm 0.64^{*}$ & $19.49 \pm 0.45^{*}$ & $19.31 \pm 0.92^{*}$ & $18.49 \pm 0.48^{*}$ & $17.46 \pm 0.42^{*}$ \\
\hline Benzene & $20.29 \pm 0.50^{\mathrm{NS}}$ & $20.04 \pm 0.86^{\mathrm{NS}}$ & $19.04 \pm 0.57^{*}$ & $14.54 \pm 0.76^{*}$ & $14.04 \pm 0.47^{*}$ \\
\hline Chloroform + benzene & $14.44 \pm 0.69^{*}$ & $15.19 \pm 0.69^{*}$ & $15.77 \pm 0.70^{*}$ & $16.44 \pm 0.40^{*}$ & $15.70 \pm 0.51^{*}$ \\
\hline Control & $21.34 \pm 0.51$ & & & & \\
\hline
\end{tabular}

Significance at $5 \%$ level; NS: no significant.

Table 4. Impact of Sargassum tenerrimum extracts on Dysdercus cingulatus reproductive parameters.

\begin{tabular}{lcccc}
\hline Extract & $\begin{array}{c}\text { Preoviposition } \\
\text { period }\end{array}$ & $\begin{array}{c}\text { Oviposition } \\
\text { period }\end{array}$ & $\begin{array}{c}\text { Post-oviposition } \\
\text { period }\end{array}$ & $\begin{array}{c}\text { Egg hatchability } \\
(\%)\end{array}$ \\
\hline Control & $3.8 \pm 0.7$ & $5.3 \pm 0.3$ & $3.3 \pm 0.5$ & $70.3 \pm 0.8$ \\
Chloroform & $3.0 \pm 0.7^{\mathrm{NS}}$ & $3.2 \pm 0.6^{*}$ & $2.7 \pm 1.2^{\mathrm{NS}}$ & $74.4 \pm 2.6$ \\
\hline
\end{tabular}

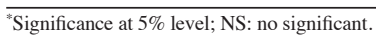

Table 5. Effect of Sargassum tenerrimum fractions on the length of nymphal developmental period (d) of Dysdercus cingulatus.

\begin{tabular}{llrr}
\hline Fractions & Third instar & Fourth instar & Fotal nymphal developmental \\
period
\end{tabular}

NS: no significant at $5 \%$ level, values in parentheses indicate number of individuals observed. 


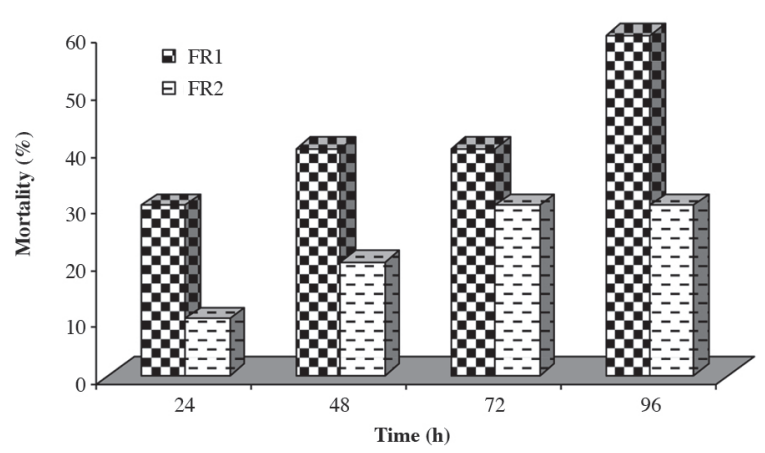

Figure 2. Sargassum tenerrimum fraction (FR1 and FR2) impact on corrected mortality of Dysdercus cingulatus third instar nymph.

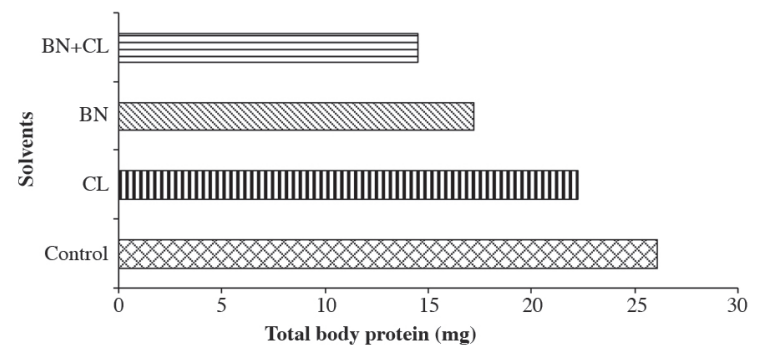

Figure 3. Impact of Sargassum tenerrimum chloroform (CH), benzene (BE), and benzene + chloroform $(\mathrm{BE}+\mathrm{CH})$ mixture extracts on total body protein (mg $100 \mathrm{mg}^{-1}$ dry weight tissue) of Dysdercus cingulatus.

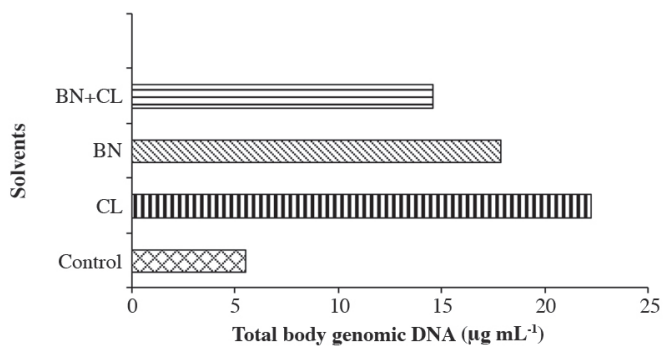

Figure 4. Impact of Sargassum tenerrimum benzene (BN), chloroform (CH) and benzene + chloroform mixture $(\mathrm{BN}+\mathrm{CH})$ extracts on total body genomic DNA content of Dysdercus cingulatus.

\section{DISCUSSION}

Sargassum (Heterokontophyta: Phaeophyceae) is a brown seaweed found along the coasts of Japan, China, Pakistan, Spain, and India. Sargassum boveanum and S. ilicifolium possess insecticidal activity against Callobruchus analis and Trigoderma grannarium (Rizvi, 2003). Rizvi and Shameel (2004) later reported the insecticidal activity of benthic algae belonging to the Chlorophyta, Phaeophyta, and Rhodophyta. Our results clearly showed that $S$. tenerrimum had insecticidal activity, and this might be due to cytotoxic oxysterol and hydroper 24 cholesterol reported in S. tenerrimum. Diverse secondary metabolites in many types of seaweed were reported as having defensive action against invertebrates in general (Hay et al., 1990) and insects in particular (Rizvi, 2003; Rizvi and Shameel, 2004; Biju et al., 2004).
Since proteins are the first biological factors manifested during development (Schmidt and Schwanki, 1975), studies about the impact of plant extracts on total body protein are very important. Total body protein content was affected in Helicoverpa armigera (Hubner) due to Artemisia annua L., Ageratum conyzoides (L.), Azadirachta indica A. Juss. (Padmaja and Rao, 2000), and Argemone mexicana L. (Malarvannan et al., 2008). Similarly, A.conyzoides reduced total body protein content of Spodoptera litura (Fab.) (Renuga and Sahayaraj, 2009).

Sargassum tenerrimum extracts and chromatographic fractions reduced nymphal and adult survival, total body protein, and DNA content in $D$. cingulatus as reported by Sahayaraj and Kalidas (2011). The dose-dependent effect of $S$. tenerrimum extracts and chromatographic fractions on $D$. cingulatus mortalitywas similar to those reported for other insect species tested with seaweed solvent extracts (Zutshi et al., 1979). Bai and Koshy (2004) reported that Thevetia neriifolia Juss. ex A. DC. leaf and seed extracts increased the $D$. cingulatus nymphal developmental period. Bai and Koshy (2004) and Sahayaraj et al. (2006) reported that neem leaf and kernel extracts, T. neriifolia leaf and seed extract, and Pedalium murex L. affect $D$. cingulatus oviposition as was observed in the present study. Bougainvillea sp. (Nyctaginaceae) and Abrus precatorius L. (Papillionaceae) interfere with D. cingulatus (Satyanarayana and Sukumar, 1988) reproduction. Insects fed with benzene and chloroform and benzene combination extracts either did not reproduce or died before attaining the egg-laying stage. This shows that there is a high variation in the ability of insects to metabolize the multiple compounds they encounter during feeding. Another reason is that $D$. cingulatus is less capable of detoxifying allelochemicals in S. tenerrimum. Sargassum tenerrimum fractions slightly prolong the $D$. cingulatus nymphal total developmental period as observed in Dysdercus koenigii (Fab.) with azadirachtin (Koul, 1984). Although development is known to be inhibited by seaweed extracts, there is no study on the effect of S. tenerrimum on insect development and DNA and protein content.

\section{CONCLUSIONS}

We conclude that the $S$. tenerrimum extracts and chromatographic fractions caused mortality, reduced the nymphal developmental period, adult longevity, egg-laying capacity, total body protein, and genomic DNA content of $D$. cingulatus. This study reveals that the red cotton bug emerged from the BN treatment and did not lay any eggs even after successful mating, thus indicating that $S$. tenerrimum caused sterility. However, further studies are essential to confirm sterility in males or females. The nymphal instars of insects are particularly sensitive to overall physiological and biochemical functions. This marine seaweed can be used to manage sucking pests such as $D$. cingulatus as an ecofriendly pest management component. The FRI has been subjected to phytochemical identification. 
Eficacia ninficida y ovicida de una alga marina Sargassum tenerrimum (J. Agardh), contra Dysdercus cingulatus (Fab.) (Pyrrhocoridae). Investigamos el rol de una alga marina café, Sargassum tenerrimum (J. Agardh), contra Dysdercus cingulatus (Fab.), una plaga económicamente importante del algodón en muchas partes de Asia. Sargassum tenerrimum ha sido usada como fuente de fertilizantes y drogas, pero en la literatura no hay información disponible sobre su uso en manejo de plagas ecoamigable. Se investigó el impacto de extractos con benceno $(\mathrm{BN})$, cloroformo $(\mathrm{CH})$, y una mezcla de ambos (BNCH) así como dos fracciones cromatográficas de $\mathrm{BNCH}$ (FR1 y FR2) por sus propiedades insecticidas y en ovipostura contra $D$. cingulatus. El extracto BE mostró la mejor actividad insecticida $\left(\mathrm{LC}_{50}=0,009 \%\right)$ que extractos $\mathrm{BNCH}\left(\mathrm{LC}_{50}=0,021 \%\right)$ y CH $\left(\mathrm{LC}_{50}=0,2481 \%\right)$ y todos los extractos redujeron el período total de desarrollo ninfal de la plaga en una manera dosis-dependiente. La longevidad de machos y hembras adultos se redujo con extractos $\mathrm{CH}$ y $\mathrm{BE}$. El extracto $\mathrm{CH}$, redujo períodos de ovipostura, prepostura y pospostura y fecundidad de $D$. cingulatus. Las hembras emergidas desde la categoría BE no pudieron oviponer. Todos los extractos redujeron significativamente el contenido de proteína corporal total y ADN genómico. Sin embargo, estas fracciones no alteraron significativamente el período de desarrollo ninfal. Estos resultados indican que estos extractos de alga pueden ser usados como biopesticidas para el manejo de plagas.

Palabras clave: Dysdercus cingulatus, plagas del algodón, ninficida, ovipostura, Sargassum tenerrimum, algas marinas, manejo de plagas.

\section{LITERATURE CITED}

Abbott, W.S. 1925. Methods for comparing the effectiveness of an insecticide. Journal of Economic Entomology 18:265-267.

Bai, H., and G. Koshy. 2004. Juvenomimetic activity of extracts of Thevetia neriifolia Juss. to Dysdercus cingulatus. F. (Hemiptera: Pyrrhocoreidae). Journal of Tropical Agriculture 42:45-47.

Biju, B., M. Jacob, K. Padmakumar, and D. Muraleedhran. 2004 Effect of extract of the seaweed Bryopsis plumosa (Huds.) (Ag) on the feeding rate and protein profile of haemolymph and fat body of Hyblaea puera (Cramer) (Lepidoptera: Hyblacidae). Entomon 29:271-276

Bradford,M.M. 1976.Arapid and sensitive method for the quantification of microgram quantities of protein utilizing the principle of proteindye binding. Annals of Biochemistry 72:248-254.

Cotcorp. 2010. The Cotton Corporation of India Ltd., Navi Mumbai, India. Available at http://cotcorp.gov.in (accessed March 2011).

Dureja, P. 1993. Pesticides from marine flora. p. 101-110. In Parmar, B.S., and C. Devakumar (eds.) Botanical and biopesticides. Westville Publishing House, New Delhi, India.

Finney, D.J. 1971. Probit analysis. $3^{\text {rd }}$ ed. Cambridge University Press, Cambridge, UK.

Harbone, J.B. 1998. Phytochemicals methods: a guide to modern techniques of plant analysis. 295 p. Chapman and Hall, London, UK.

Hashim, M.S., and K.S. Devi. 2003. Insecticidal action of the polyphenolic rich fractions from the stem bark Streblus asper on Dysdercus cingulatus. Fitoterapia 744:670-676.

Hay, M.E., J.E. Duffy, V.J. Paul, P.E. Renaud, and W. Fenical. 1990. Specialist herbivores Avrainvillea longicaulis. Limnology and Oceanography 35:1734-1743
Iwata, K. 1975. Slizen kansatsusha no suki. (Memories on nature by an observer). 584 p. Ashi Shimbun Co, Tokyo, Japan (in Japanese).

Kohno, K., and N.B. Thi. 2004. Effects of host plant species on the development of Dysdercus cingulatus. (Heteroptera: Pyrrhocoridae). Applied Entomology and Zoology 39:183-187.

Koul, O. 1984. Azadirachtin-interaction with the development of red cotton bugs. Entomology Experimental et Applicata 36:85-88

Malarvannan, S., R. Giridharan, S. Sekar, V.R. Prabavathy, and Sudha Nair. 2008. Bioefficacy of crude and fractions of Argemone mexicana against tobacco caterpillar, S. litura Fab. (Noctuidae: Lepidoptera). Journal of Biopesticides 1:55-62.

Manilal, A., S. Sujith, G. Seghal Kiran, J. Selvin, C. Shakir, R. Gandhimathi, and M.V. Natraja Panikkar. 2009. Biopotentials of seaweeds collected from southwest coast of India. Journal of Marine Science and Technology 17:67-73.

Natarajan, K., and T.P. Rajendran. 2005. Pest management in cotton in DUS experimentation. p. 124-135. In Rathinavel, K., S Manickam, and M. Sabes (eds.) DUS testing in cotton. All India Coordinated Cotton Improvement Project, Central Institute for Cotton Research Regional Station, Coimbatore, India.

Padmaja, P.G., and P.J. Rao. 2000. Efficacy of certain plant oils on the American bollworm Helicoverxa armigera Hubner. Pesticide Research Journal 12:107-111.

Rajendran, B., and M. Gopalan. 1980. Juvenile hormone like activity of certain plant extracts on Dysdercus cingulatus Fabricius (Heteroptera: Pyrrhocoridae). Indian Journal Agricultural Science $50: 781-784$

Renuga, F.B., and K. Sahayaraj. 2009. Influence of botanicals in total head protein of Spodoptera litura (Fab.) Journal of Biopesticides 2:52-55.

Rizvi, M.A. 2003. Bioactivity, elementology and econo-medicinal importance of certain sea weeds from Karachi coast. 367 p. PhD Thesis. University of Karachi, Department of Botany, Karachi, Pakistan.

Rizvi, M.A., and M. Shameel. 2003. Biological activity and elementology of benthic algae from Karachi coast. Pakistan Journal of Botany 35:717-729.

Rizvi, M.A., and M. Shameel. 2004. Studies on the bioactivity and elementology of marine algae from the coast of Karachi Pakistan. Phytochemical Research 18:865-872.

Sahayaraj, K., R.J. Alakiaraj, and J.F. Borgio. 2006. Ovicidal and ovipositional effect of Pedalium murex Linn (Pedaliaceae) root on Dysdercus cingulatus (Fab.) (Hemiptera: Pyrrhocoridae). Entomon 31:57-60.

Sahayaraj, K., and R. Ilyaraja. 2008. Ecology of Dysdercus cingulatus morphs. Egyptian Journal of Biology 10:122-125.

Sahayaraj, K., and S. Kalidas. 2011. Evaluation of nymphicidal and ovicidal effect of seaweed, Padina pavonica (Linn.) (Phaeophyceae) on cotton pest, Dysdercus cingulatus (Fab.) Indian Journal of Marine Sciences 40:125-129.

Sambrook, J., E.F. Fritsch, and T. Maniatis. 1989. Molecular cloning: a laboratory manual. $2^{\text {nd }}$ ed. Cold Spring Harbor Laboratory, New York, USA.

Satyanarayana, A., and K. Sukumar. 1988. Phytosterilants to control the cotton bug Dysdercus cingulatus F. Current Science 57:918919.

Schmidt, W., and S. Schwanki. 1975. Changes in haemolymph proteins during the metamorphosis of both sexes and casts of Polygynous formicarufa. Comparative Biochemistry Physical B 52:305-380.

Sharma, T., A. Qamar, and A. M. Khan. 2010. Evaluation of neem (Azadirachta indica) extracts against the eggs and adults of Dysdercus cingulatus (Fab.). World Applied Sciences Journal 9:398-402.

Yasuda, K. 1992. Cotton bug. p. 22-23. In Hidaka, T. (ed.) Insects pests of vegetables in tropics, Association for International Cooperation on Agriculture and Forestry, Tokyo, Japan.

Zutshi, M., Y. Saxena, and A. Jayadevi. 1979. Effect of juvenile hormone analogue ZR-515 on the last instar nymphs of Dysdercus cingulatus (Fab) (Heteroptera: Pyrrhocoridae). Current Science 48(2):89-90. 